\title{
Correction
}

\section{Correction to: From Jean Leray to the millennium problem: the Navier-Stokes equations}

\author{
REINHARD FARWIG(D)
}

\section{Correction to: J. Evol. Equ. https://doi.org/10.1007/s00028-020-00645-3}

The article "From Jean Leray to the millennium problem: the Navier-Stokes equations", written by Farwig, R., was originally published electronically on the publisher's internet portal on 9 November 2020 without open access. With the author(s)' decision to opt for Open Choice the copyright of the article changed on 26 April 2021 to $($ ) The Author(s) 2020 and the article is forthwith distributed under a Creative Commons Attribution 4.0 International License, which permits use, sharing, adaptation, distribution and reproduction in any medium or format, as long as you give appropriate credit to the original author(s) and the source, provide a link to the Creative Commons licence, and indicate if changes were made. The images or other third party material in this article are included in the article's Creative Commons licence, unless indicated otherwise in a credit line to the material. If material is not included in the article's Creative Commons licence and your intended use is not permitted by statutory regulation or exceeds the permitted use, you will need to obtain permission directly from the copyright holder. To view a copy of this licence, visit http://creativecommons.org/ licenses/by/4.0/. Open access funding enabled and organized by Projekt DEAL.

Open Access. This article is licensed under a Creative Commons Attribution 4.0 International License, which permits use, sharing, adaptation, distribution and reproduction in any medium or format, as long as you give appropriate credit to the original author(s) and the source, provide a link to the Creative Commons licence, and indicate if changes were made. The images or other third party material in this article are included in the article's Creative Commons licence, unless indicated otherwise in a credit line to the material. If material is not included in the article's Creative Commons licence and your intended use is not permitted by statutory regulation or exceeds the permitted use, you will need to obtain permission

The original article can be found online at https://doi.org/10.1007/s00028-020-00645-3. 
directly from the copyright holder. To view a copy of this licence, visit http://creativecommons.org/licenses/ by/4.0\%.

Publisher's Note Springer Nature remains neutral with regard to jurisdictional claims in published maps and institutional affiliations.

\author{
Reinhard Farwig \\ Fachbereich Mathematik \\ Technische Universität Darmstadt \\ Schlossgartenstraße 7 \\ 64289 Darmstadt \\ Germany \\ E-mail: $\quad$ farwig@mathematik.tu- \\ darmstadt.de
}

